\title{
EFFECT OF INTERMITTENT POSITIVE PRESSURE BREATHING ON PULMONARY CIRCULATION IN EMPHYSEMA
}

\author{
BY \\ J. J. DALY AND R. S. DUFF \\ From the University Department of Medicine, Royal Hospital and City General Hospital, Sheffield \\ Received February 22, 1962
}

\begin{abstract}
Pulmonary hypertension in emphysema is thought to be due to a combination of structural damage to the lung and vasoconstriction (Ferrer and Harvey, 1959). Experimental observations in the dog (Nahas et al., 1954) and man (Cournand, 1950) indicate that hypoxia causes pulmonary vasoconstriction. Therefore hypoxia in emphysema may contribute to the increase of pulmonary arterial pressure. However, correction of hypoxia in emphysematous subjects has not consistently resulted in a decrease of pulmonary arterial pressure (Westcott et al., 1951; Mounsey et al., 1952; Wilson, Hoseth and Dempsey, 1955) and this suggests that some other factor may be responsible. There is clinical evidence that when $\mathrm{CO}_{2}$ retention occurs in patients with emphysema, severe pulmonary arterial hypertension develops (Fishman and Richards, 1956; Harvey et al., 1951). The present study was designed to investigate the effect of a decrease in arterial $\mathrm{Pco}_{2}$ produced by mechanical hyperventilation on the pulmonary circulation of patients with emphysema.
\end{abstract}

\section{METHODS}

Ten men aged between 34 and 74 years who had emphysema were studied. None had congestive cardiac failure or evidence of respiratory infection at the time of investigation.

A cardiac catheter was introduced into the pulmonary artery and an indwelling needle was inserted into a brachial or femoral artery. Cardiac output was estimated by the Fick method in 8 , and pulmonary arterial pressure was recorded in all subjects. After an interval of 15 to 30 minutes each subject was given intermittent positive pressure respiration (I.P.P.R.) with air for between 12 and 20 minutes. The respirator was modified so that expired gas could be collected and the valve was triggered by the subject with the respiratory rate maintained as near as possible to the resting value. The positive pressure respirator was adjusted so that the mean mask pressure during a respiratory cycle did not exceed $6 \mathrm{~mm}$. $\mathrm{Hg}$ and the pressure during the expiratory phase fell moderately rapidly to near atmospheric. These adjustments were made in order to minimize the mechanical effects on the circulation (Cournand et al., 1948) but it was recognized that in some instances the change in ventilation might be small. During the last three minutes of I.P.P.R. a second estimate of cardiac output was obtained in five subjects and the pulmonary arterial pressure recorded.

Pressures were measured using a Southern Instruments capacitance manometer and recorded on a poly-viso Sanborn recorder. Expired gas was analysed for $\mathrm{CO}_{2}$ and $\mathrm{O}_{2}$ content using a Scholander apparatus (Scholander, 1947), and gas volumes measured using a wet test meter. The $\mathrm{O}_{2}$ content, capacity, and $\mathrm{CO}_{2}$ content of blood samples were measured by the method of Van Slyke and Neill (1924). The $p \mathrm{H}$ of arterial blood samples was measured at room temperature using a Marconi Instruments $p \mathrm{H}$ meter with a glass electrode, and values were corrected to $38^{\circ} \mathrm{C}$. (Rosenthal, 1948). Arterial $\mathrm{PcO}_{2}$ was obtained from the $\mathrm{CO}_{2}$ content, $p \mathrm{H}$, and hæmatocrit, using the nomogram of Singer and Hastings (1948). 


\section{RESULTS}

Table I shows the values for mean pulmonary arterial pressure, arterial $\mathrm{PcO}_{2}$, and $\mathrm{O}_{2}$ saturation at rest and during I.P.P.R.

TABLE I

arterial Oxygen Saturation, Carbon Dioxide Tension, Pulmonary Arterial Pressure, and Cardiac Output AT REST AND DURING I.P.P.R.

\begin{tabular}{|c|c|c|c|c|c|c|c|}
\hline \multicolumn{2}{|c|}{ Subject } & $\underset{\text { (years) }}{\text { Age }}$ & $\begin{array}{l}\mathrm{A}^{*} \\
\mathrm{~B}^{\dagger}\end{array}$ & $\mathrm{SaO}_{2}$ & $\mathrm{PacO}_{2}$ & $\begin{array}{l}\text { Mean pulmonary } \\
\text { arterial pressure } \\
(\mathrm{mm} . \mathrm{Hg})\end{array}$ & $\begin{array}{l}\text { Cardiac output } \\
\text { 1./min. }\end{array}$ \\
\hline D.R. & .. & 37 & A & 78 & - & 64 & $6 \cdot 3$ \\
\hline & & & B & 79 & $\overline{61}$ & 60 & $\begin{array}{l}6 \cdot 7 \\
4.5\end{array}$ \\
\hline P.D. & .. & 45 & $\begin{array}{l}\text { A } \\
\text { B }\end{array}$ & $\begin{array}{l}88 \\
91\end{array}$ & $\begin{array}{l}64 \\
53\end{array}$ & $\begin{array}{l}27 \\
20\end{array}$ & $\begin{array}{l}4 \cdot 5 \\
3 \cdot 6\end{array}$ \\
\hline H.C. & .. & 60 & A & 86 & 50 & 46 & $5 \cdot 7$ \\
\hline $\mathrm{T} C$ & & 58 & B & $\begin{array}{l}89 \\
88\end{array}$ & $\begin{array}{l}43 \\
52\end{array}$ & $\begin{array}{l}37 \\
19\end{array}$ & $\begin{array}{l}6.0 \\
7.9\end{array}$ \\
\hline 1.C. & . & 58 & ${ }_{\mathbf{B}}^{\mathbf{A}}$ & $\begin{array}{l}80 \\
83\end{array}$ & 34 & 15 & $8 \cdot 8$ \\
\hline J.M. & .. & 74 & A & $\begin{array}{l}53 \\
59\end{array}$ & 123 & $\begin{array}{l}58 \\
60\end{array}$ & $\begin{array}{l}8 \cdot 2 \\
9 \cdot 3\end{array}$ \\
\hline J.B. & .. & 60 & A & 76 & $\begin{array}{r}121 \\
68\end{array}$ & $\begin{array}{l}60 \\
49\end{array}$ & $\begin{array}{l}9 \cdot 3 \\
3.9\end{array}$ \\
\hline$H G$ & & 61 & B & 92 & $\begin{array}{l}57 \\
40\end{array}$ & $\begin{array}{l}39 \\
28\end{array}$ & $\begin{array}{c}7 \cdot 4 \ddagger \\
11 \cdot 4\end{array}$ \\
\hline H.G. & $\cdots$ & 01 & B & 65 & 36 & 23 & \\
\hline B.H. & .. & 58 & A & 67 & 84 & 28 & 8.4 \\
\hline J.R. & .. & 60 & A & 88 & 43 & 23 & \\
\hline & $\ldots$ & 54 & $\begin{array}{l}\text { B } \\
\text { A }\end{array}$ & $\begin{array}{l}92 \\
90\end{array}$ & $\begin{array}{l}41 \\
43\end{array}$ & $\begin{array}{l}15 \\
17\end{array}$ & \\
\hline & & & B & 85 & 47 & 15 & \\
\hline
\end{tabular}

* Resting period.

$\dagger$ Intermittent positive pressure respiration. $\ddagger$ Venous blood sample from right atrium.

The resting arterial $\mathrm{O}_{2}$ saturation was less than 95 per cent in all 10 subjects, ranging from $53^{\circ}$ to 90 per cent. The arterial $\mathrm{PcO}_{2}$ was greater than normal in 6 subjects, ranging from 50 to $123 \mathrm{~mm}$. $\mathrm{Hg}$, and in 3 subjects it was within the normal range. Estimates of cardiac output were obtained in 8 and these initially averaged $7.01 . / \mathrm{min}$. (range $3.9-11.41 . / \mathrm{min}$.). The resting mean pulmonary arterial pressure ranged between 17 and $64 \mathrm{~mm}$. $\mathrm{Hg}$, exceeding $25 \mathrm{~mm}$. $\mathrm{Hg}$ in 7 subjects.

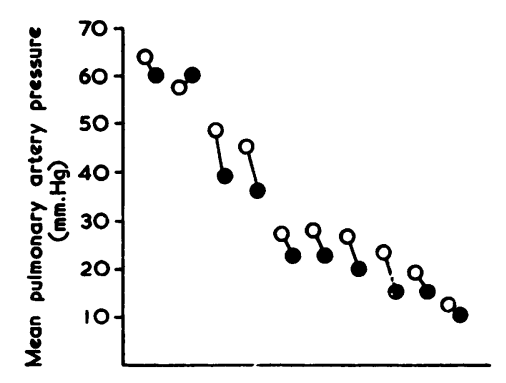

FIG. 1.-Mean pulmonary arterial pressure at rest (open circles) and during I.P.P.R. (dark circles) in 10 subjects.

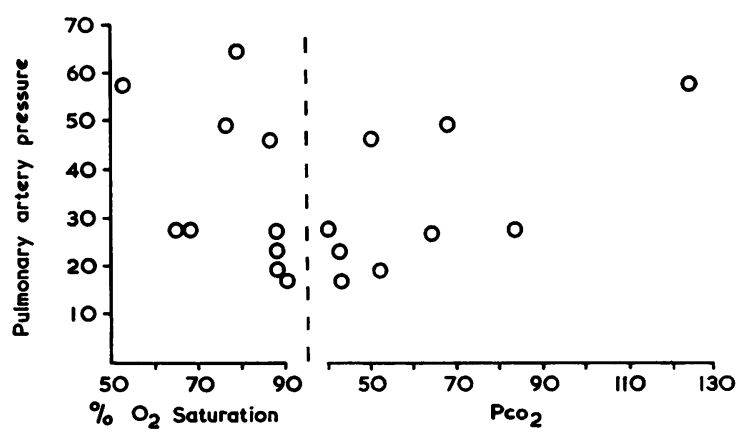

FIG. 2.-Resting arterial oxygen saturation and $\mathrm{PcO}_{2}$ at rest plotted against mean pulmonary arterial pressure. 
Effect of I.P.P.R. During the last three minutes of mechanical hyperventilation the arterial $\mathrm{O}_{2}$ saturation increased in 7 subjects but did not reach normal in any instance; in 1 subject the $\mathrm{O}_{2}$ saturation was unchanged; and in the remaining 2 it decreased by 5 per cent. The arterial $\mathrm{PcO}_{2}$ decreased in 8 subjects and increased slightly in 1, with an average decrease of $9 \mathrm{~mm}$. $\mathrm{Hg}$. The mean pulmonary arterial pressure during I.P.P.R. decreased in 9 of the 10 subjects, by an average of $6 \mathrm{~mm}$. $\mathrm{Hg}$ : an increase of $2 \mathrm{~mm}$. $\mathrm{Hg}$ occurred in the remaining subject (Fig. 1). Cardiac output increased in 4 and decreased in 1 subject during I.P.P.R. (Table I), the mean change being an increase of about 11./min. Table II gives the $\mathrm{O}_{2}$ consumption and respiratory quotients before and during I.P.P.R. in these 5 subjects. There were no large variations in these values.

TABLE II

Oxygen Consumption (A-V) $\mathrm{O}_{2}$ Differences, and Respiratory Quotients in Six Subjects before and during I.P.P.R.

\begin{tabular}{|c|c|c|c|c|}
\hline Subject & $\begin{array}{l}\text { A* }^{*} \\
\text { B } †\end{array}$ & $\begin{array}{l}\mathrm{Vo}_{2} \mathrm{ml} . \\
\text { (S.T.P.D.) }\end{array}$ & $\begin{array}{c}(\mathrm{A}-\mathrm{V}) \mathrm{O}_{2} \\
\text { differences }\end{array}$ & R.Q. \\
\hline $\begin{array}{ll}\text { D.R. } & \ldots \\
\text { P.D. } & \ldots \\
\text { H.C. } & \ldots \\
\text { J.B. } & \ldots \\
\text { T.C. } & \text {. } \\
\text { J.M. } & \text {. }\end{array}$ & $\begin{array}{l}\text { A } \\
\text { B } \\
\text { A } \\
\text { B } \\
\text { A } \\
\text { B } \\
\text { A } \\
\text { B } \\
\text { A } \\
\text { B } \\
\text { A } \\
\text { B }\end{array}$ & $\begin{array}{l}271 \\
302 \\
190 \\
210 \\
338 \\
372 \\
213 \\
273 \\
284 \\
293 \\
222 \\
195\end{array}$ & $\begin{array}{l}4 \cdot 3 \\
4 \cdot 5 \\
4 \cdot 2 \\
5 \cdot 8 \\
5 \cdot 9 \\
6 \cdot 2 \\
5 \cdot 4 \\
3 \cdot 7 \ddagger \\
3 \cdot 6 \\
3 \cdot 3 \\
2 \cdot 7 \\
2 \cdot 1\end{array}$ & $\begin{array}{l}0.80 \\
0.80 \\
0.77 \\
0.87 \\
0.74 \\
0.90 \\
0.83 \\
0.79 \\
0.86 \\
0.96 \\
0.74 \\
0.81\end{array}$ \\
\hline
\end{tabular}

* Resting period. $\ddagger$ Venous blood sample from right atrium.

\section{DISCUSSION}

The range of resting values of arterial $\mathrm{O}_{2}$ saturation, arterial $\mathrm{PcO}_{2}$, pulmonary arterial pressure, and cardiac output in this group of patients with emphysema is comparable with that reported by others (Harvey et al., 1951; Mounsey et al., 1952).

The increase in mean intrathoracic pressure during I.P.P.R. is transmitted equally to the blood vessels in the thorax, and the recorded pulmonary arterial pressure will include this effect. In 9 of the 10 subjects a decrease in pulmonary arterial pressure occurred during I.P.P.R. It has previously been demonstrated that during I.P.P.R. the level of mean mask pressure and the shape of the pressure curve influence the cardiac output (Cournand et al., 1948). In the present investigation the respirator was adjusted to minimize the mechanical effects on the circulation. The cardiac output increased slightly in 4 of 5 subjects during I.P.P.R. In 3, this increase was associated with a decrease in mean pulmonary arterial (P.A.) pressure. These changes provide evidence of a decrease in pulmonary vascular resistance. In the fourth subject cardiac output increased by 13 per cent and pressure by 3 per cent. The greater percentage increase in blood flow compared with mean P.A. pressure is also evidence for a decrease in pulmonary vascular resistance. In the absence of estimates of cardiac output the decrease in P.A. pressure in 5 subjects cannot be interpreted. However, the average effect of I.P.P.R. in the other 5 did not lead to a reduction in cardiac output.

In no subject was anoxia abolished during I.P.P.R., and such small changes in arterial oxygen saturation as did occur might not be expected to influence the pulmonary arterial pressure. Kitchin, Lowther, and Mathews (1961) found no significant change in the resting pulmonary arterial pressure of emphysematous subjects whose anoxia was corrected by giving 66 per cent oxygen. In view of 
these findings the present results indicate a closer relation between the fall in P.A. pressure and the decrease in arterial $\mathrm{Pco}_{2}$ rather than the change in arterial oxygen saturation. There is, however, no evidence that in normal man hypercapnia alters the pulmonary vascular resistance. $\mathrm{CO}_{2}$ retention and hypoxia produced by hypoventilation resulted in an increase in pulmonary arterial pressure in anæsthetized subjects, but with correction of the $\mathrm{O}_{2}$ saturation alone the pulmonary pressure reverted towards normal (Bühlmann and Hossli, 1956; Bühlmann, Schaub, and Rossier, 1954). No evidence of pulmonary vasoconstriction was obtained by Fishman, Fritts, and Cournand (1960) in emphysematous subjects with inhalation of $\mathrm{CO}_{2}$. Therefore, it is unlikely that any changes in pulmonary vascular resistance in the present study were directly due to changes in arterial $\mathrm{PcO}_{2}$.

In conclusion it can be stated that the changes in the pulmonary circulation were more closely related to the simultaneous decrease in arterial $\mathrm{Pco}_{2}$ than to changes in arterial $\mathrm{O}_{2}$ saturation.

\section{SUMMARY}

Ten men with emphysema were studied by cardiac catheterization at rest and during intermittent positive pressure respiration with air. In all but one the mean pulmonary arterial pressure fell during I.P.P.R., the cardiac output increased in 4 out of 5, and there was evidence of a fall in pulmonary vascular resistance in these 4 subjects. With I.P.P.R. the arterial oxygen saturation increased in most subjects, but hypoxia was not fully corrected in any: the arterial $\mathrm{PcO}_{2}$ decreased in 8 out of 9 subjects. The hæmodynamic changes were more closely related to the decrease in arterial $\mathrm{PCO}_{2}$ than to the increase in arterial $\mathrm{O}_{2}$ saturation.

Some of the apparatus used in this work was provided out of Research Fund Grant No. 340, University of Sheffield. We are indebted to Professor C. H. Stuart-Harris, C.B.E., for constant encouragement and advice, and to Nurse Davies, Cardiovascular Unit, City General Hospital, for efficient help.

\section{REFERENCES}

Bühlmann, A., and Hossli, G. (1956). Hämodynamische Untersuchungen bei akuter Hypoventilation. Schweiz. med. Wschr., 86, 681.

—, Schaub, F., and Rossier, P. H. (1954). Zur Ätiologie und Therapie des Cor pulmonale. Schweiz. med. Wschr., 84, 587.

Cournand, A. (1950). Some aspects of the pulmonary circulation in normal man and in chronic cardiopulmonary diseases. Circulation, 2, 641.

- - Motley, H. L., Werko, L., and Richards, D. W., Jr. (1948). Physiological studies of the effects of intermittent positive pressure breathing on cardiac output in man. Amer. J. Physiol., 152, 162.

Ferrer, M. I., and Harvey, R. M. (1959). In Pulmonary Circulation, edited by W. R. Adams, and I. Veith, p. 171. Grune and Stratton, New York and London.

Fishman, A. P., Fritts, H. W., Jr., and Cournand, A. (1960). Effects of breathing carbon dioxide upon the pulmonary circulation. Circulation, 22, 220.

—, and Richards, D. W. (1956). The Management of cor pulmonale in chronic pulmonary disease, with particular reference to the associated disturbances in the pulmonary circulation. Amer. Heart J., 52, 149.

Harvey, R. M., Ferrer, M. I., Richards, D. W., and Cournand, A. (1951). Influence of chronic pulmonary disease on the heart and circulation. Amer. J. Med., 10, 719.

Kitchin, A. H., Lowther, C. P., and Matthews, M. B. (1961). The effects of exercise and of breathing oxygen-enriched air on the pulmonary circulation in emphysema. Clin. Sci., 21, 93.

Mounsey, J. P. D., Ritzmann, L. W., Selverstone, N. J., Briscoe, W. A., and McLemore, G. A. (1952). Circulatory changes in severe pulmonary emphysema. Brit. Heart J., 14, 153.

Nahas, G. G., Visscher, M. B., Mather, G. W., Haddy, F. J., and Warner, H. R. (1954). Influence of hypoxia on the pulmonary circulation of nonnarcotized dogs. J. appl. Physiol., 6, 467.

Rosenthal, T. B. (1948). The effect of temperature on the pH of blood and plasma in vitro. J. biol. Chem., $173,25$.

Scholander, P. F. (1947). Analyzer for accurate estimation of respiratory gases in one-half cubic centimeter samples. J. biol. Chem., 167, 235.

Singer, R. B., and Hastings, A. B. (1948). An improved clinical method for the estimation of disturbances of the acid-base balance of human blocd. Medicine, 27, 223.

Van Slyke, D. D., and Neill, J. M. (1924). The determination of gases in blood and other solutions by vacuum extraction and manometric measurement. J. biol. Chem., 61, 523.

Westcott, R. N., Fowler, N. O., Scott, R. C., Hauenstein, V. D., and McGuire, J. (1951). Anoxia and human pulmonary vascular resistance. J. clin. Invest., 30, 957.

Wilson, R. H., Hoseth, W., and Dempsey, M. E. (1955). The effects of breathing 99.6 per cent oxygen on pulmonary vascular resistance and cardiac output in patients with pulmonary emphysema and chronic hypoxia. Ann. intern. Med., 42, 629. 